\title{
Utilization of entrepreneurial information among rural women farmers in Akinyele Local Government Area Oyo State
}

\author{
Ogunwale, O.G.; Ojo-Fakuade, F.F.; Oyewole, O.O.; Olayemi, O.O. and \\ Babatunde, R.O
}

Department of Agricultural Extension and Management, Federal College of Forestry, Ibadan, Oyo State, Nigeria

*corresponding author: Ghislaine NDONKEU MANGOUMOU, ndonkeumang@ gmail.com

\begin{abstract}
Entrepreneurship on a small scale is the only solution to the problems of unemployment and proper utilization of both human and non-human resources and improving the leaving conditions of the poor masses. Therefore, Utilization of entrepreneurial information among rural women farmers in Akinyele Local Government Area Oyo State was investigated. 200 respondents with the aid of well structured questionnaire were selected through Multi-stage sampling technique. Data were analyzed using frequency counts, percentage and means and PPMC at 0.05\% level of significance. The result of analysis revealed that most $45.5 \%$ of respondents are in their active age, married with majority (41.5\%) had farming experience between 16 years and above. Also, utilization of entrepreneurial information among women farmers is high. However, Securing working capital, lack of transportation, lack of information and delay of payment, high cost of labor and high cost of inputs are major constraints faced by rural women farmers in the study area. PPMC Analysis reveals that there is significant relationship between constraints faced by rural women farmers and utilization of entrepreneurial information ( $r$-value $=0.365$ and $p$-valve $=0.000$ ). It is therefore recommended that Rural women farmers should be introduced to the internet, in order to get more information on entrepreneurship. And also, various tiers of government should create programs that will catalyze entrepreneurial development with the aid entrepreneur information (with special focus for women) in the rural areas.
\end{abstract}

Keywords - Utilization, Rural, Women farmers, Entrepreneurial information.

\section{INTRODUCTION}

Rural women are active agents of economic and social change and environmental protection who are, in many ways and to various degrees, constrained in their roles as farmers, producers, investors, caregivers and consumers. They play crucial roles ensuring food and nutrition security, eradicating rural poverty and improving the well-being of their families yet continue to face serious challenges as a result of gender based stereotypes and discrimination that deny them equitable access to opportunities, resources, assets and services. Women are the backbone of the rural economy, especially in the developing world. Yet they receive only a fraction of the land, credit, inputs (such as improved seeds and fertilizers), agricultural training and information compare to men. Empowering and investing in rural women as been shown to significantly increase productivity, reduce hunger, and malnutrition and improve rural livelihood.

Information utilization is particularly important to entrepreneur's final decision because information is deemed to be worthless if it is not put to good use (Ottun and Moore 1997), Suggest that information utilization be conceptualized in terms of type and extent of usage in the decision making process. Information is the powerful knowledge resource that can enhance competitive advantage. In particularly information pertaining to customers and competitors are crucial towards the development of market orientation. Information acquisition and utilization is an important activity particularly salient for firms that have high levels of 
entrepreneurial orientation. Information on entrepreneurship should not just be gathered, but should be well used. Utilization and acquisition of entrepreneurial information is very important for an excellent performance in business.

(According to Pleter (2005), the entrepreneurs are business people who build (start), develop and manage a business, risking time, efforts and money to this purpose. The entrepreneurship as a concept refers to an ability of the individual to put into practice an idea possessing some qualities such as creativity, innovation, risk taking, and ability to plan and manage the activities in view of fulfilling the proposed goals. This term knows different approaches at the level of each state, being influenced by certain elements such as education, culture, and environment, legislative and political system (Piti, 2010). The managerial and self-control qualities of the entrepreneur have evolved as two new major dimensions of their personality, in addition to the traditional concept that the entrepreneurs are involved in risk taking, that is, they are innovative and creative (Biswas, 2000). The recognition and evaluation of business opportunities represents the beginning of the entrepreneurial process (Baron and Henry, 2010). The individual entrepreneur detects or creates business opportunities that he then exploits by small and medium size enterprises, usually taking part in the financing of capital for that company, or merely, "he sells" the idea of the business project (Cuervo et al, 2010). It is against this backdrop that this research investigated the extent of Utilization of entrepreneurial information among rural women farmers in Akinyele Local Government Area Oyo State with the following specific objectives;

1. To identify the socio economic characteristics of the respondent in the study area.

2. To assess the utilization of entrepreneurial information among rural women farmers in the study area.

3. To ascertain the constraint faced by rural women farmers in the utilization of entrepreneurial information in the study area.

\section{Hypothesis of the study}

Ho1 - There is no significant relationship between constraints faced by rural women farmers and utilization of entrepreneurial information in the study area.

\section{MATERIALS AND METHODS}

The study was carried out in Akinyele Local government area which was created in 1976 with the administrative headquarters located at Moniya. The local government shares the same boundaries with Afijo local government to the north, Lagelu local government area to the east, Ido local government area to the west and Ibadan north local government area to the south. It occupies a land area of 464.892square kilometers with a population density of 516 persons per square kilometer. Using 3.2\% growth rate from 2006 census figures, the 2010 estimated population for the local government is 239,745 . It is dominated by the Yoruba's among other resident tribes such as Ibo, Tiv, Hausa, Nupe, Fulani etc. The residents are of Christianity, Islamic, and traditional religion. The L.G.A. is endowed with fertile agricultural land suitable for the cultivation of crops like orange, mango, banana, pineapple, cassava, yam etc. The area is also notable for palm oil production.

\section{Sampling Procedure and Sample size}

Multistage sampling techniques were used to select respondents in the study area. First stage involved randomly selecting six (6) out of twelve wards in Akinyele local government area, Oyo state, Nigeria. Second stage involved purposively selecting twenty (20) villages/communities from the randomly selected wards. Third stage involved randomly selecting Ten (10) respondents in each of the twenty (20) purposively selected villages/ communities, which account for a total of two hundred (200) respondents used as sample size for the study.

\section{Data Analysis}

Descriptive statistics such as frequency distribution, percentage was used to analyses all objectives while PPMC for hypothesis of the study. 


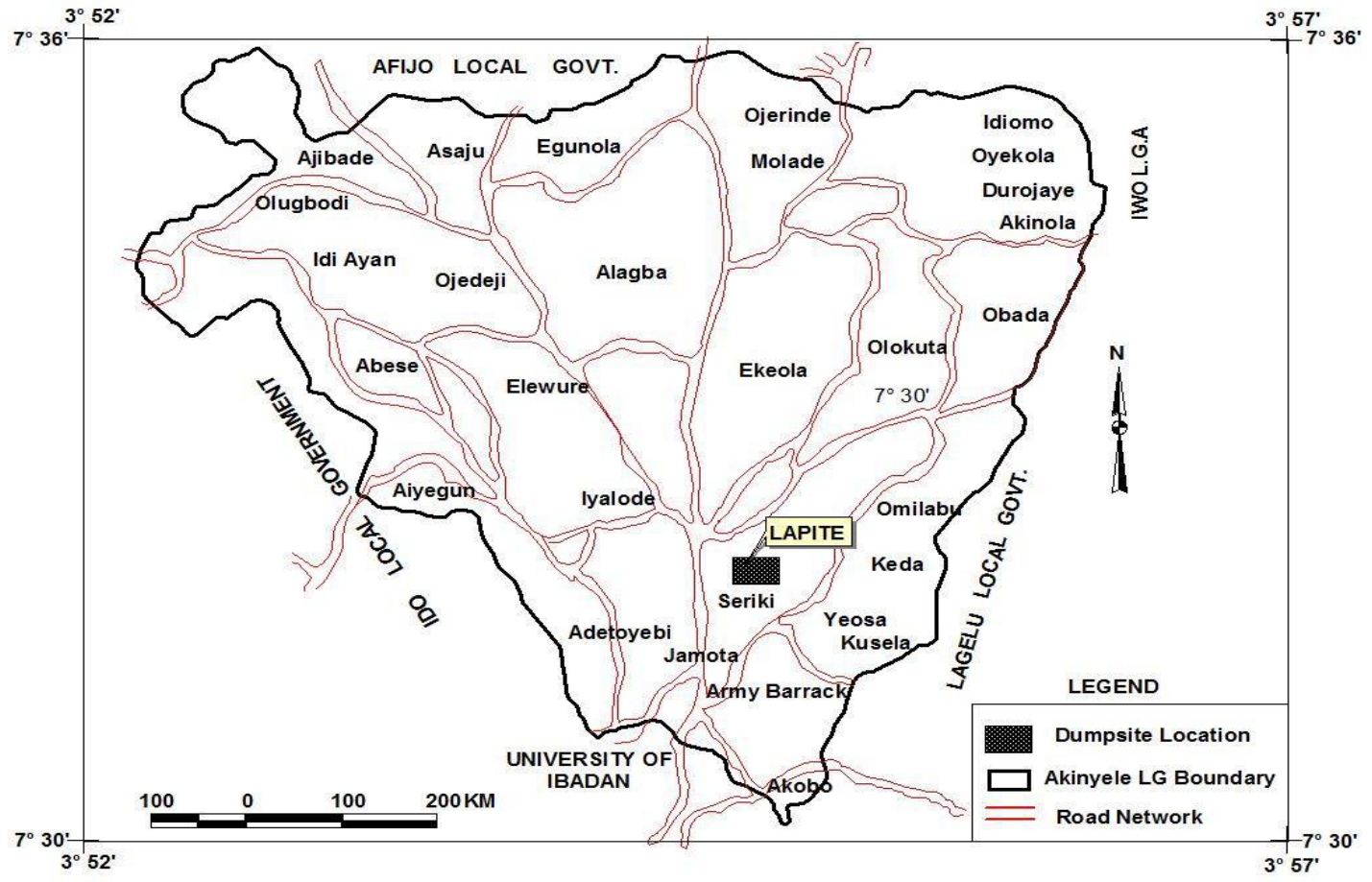

\section{RESULTS AND DISCUSSION}

\section{Socio-economic characteristics of respondents}

The result of analysis in Table 1 shows that $45.5 \%$ of the respondents fall within the age range of 31-40 years age bracket, $25.0 \%$ were between the age range of $41-50,22.5 \%$ follows between the age range of 50 and above, while only $7.0 \%$ between the age range of 20-30. The result shows that the range of 31-40 have the highest percentage; this implies that most of women farmers are still in their active age. This agrees with the finding of Odebode (2008) who reported that perception and acceptability of innovation is mainly associated with youthful and active age of farmers. Also, the table shows that $(85.5 \%)$ of the respondents were married, $(7.5 \%)$ were widowed, $(6.5 \%)$ were single, while $(0.5 \%)$ were divorced. This is supported with the findings of Adelore et al (2006) that most farmers are married. Based on their educational level, result shows that $(28.0 \%)$ of the respondents has primary education $(23.5 \%)$ of the respondents has adult education, (20.0\%) of the respondents had no formal education, (19.5\%) of the respondents had secondary education, and $(9.0 \%)$ of the respondents had tertiary education. This implies that majority of the women farmers within the study area are not well educated. Furthermore, Table 1 (55.5\%) of the respondents were Christians while $(44.5 \%)$ of the respondents were Muslims. More so, the result also shows that respondents with household size of $1-4$ were $(38.0 \%)$, 5-8 were $(52.5 \%)$ while 9 and above were $(9.5 \%)$. This implies that the larger the household size the more labor availability and the more income requirement to meet household needs. Also, (73.0\%) Of the respondents had their secondary occupation as trading. This means they have another job apart from being a farmer which can be used to generate more income into the family. The result above further shows that, (4.0\%) of the respondents had farming experience between 1-5years, (23.5\%) had farming experience between 6-10years, (31.0\%) had farming experience of between 11-15years, while $(41.5 \%)$ had farming experience between 16 years and above.

Table 1: Socio economic characteristics of the respondents

\begin{tabular}{llc}
\hline Variable & Frequency & Percentage \\
\hline Age & & \\
$20-30$ & 14 & 7.0 \\
$31-40$ & 91 & 45.5
\end{tabular}

ISSN: 2456-1878 
41-50

Above 50

\section{Marital Status}

Single

Married

Divorce

Widow

\section{Educational Level}

Adult education

No formal education

Primary education

Secondary education

Tertiary education

\section{Religion}

Christian

Islam

Traditional

\section{Household size}

1-4

5-8

9 above

\section{Secondary occupation}

Farming

Trading

Teaching

Others

\section{Farming experience}

1-5

6-10

11-15

16 above

Total
50

45

13

171

1

15

47

40

53

39

18

111

86

3

76

105

19

21

146

15

18

\section{8}

47

62

83
25.0

22.5

6.5

85.5

0.5

7.5

23.5

20.0

28.0

19.0

9.0

55.5

44.5

1.5

38.0

52.5

9.5

10.5

73.0

7.5

9.0

4.0

23.5

31.0

41.5

100
Source: field survey 2018

The result shows that majority of the respondents $71.5 \%$ and $59.5 \%$ respectively rely heavily on the information acquired on entrepreneurship and make use of different types of support that is offered to people who want to start their own business respectively. This implies that knowledge is shared out so as to acquire more because no man is an island of knowledge. Also, the table shows that $29.5 \%$ of the respondents never delegates tasks and responsibilities to their employees.Also, $85.5 \%$ of the respondents persist in the face of their adversity because an entrepreneur is confronted with 
various risks and an entrepreneur that cannot persist in the face of adversity may likely not succeed. So also, $48.5 \%$ and $46.0 \%$ of the respondents manage the financial records of their business and maintain the record respectively. This implies that it will be easier to identify if they are running at lose or making profit.Also, $69.0 \%$ of the respondents were able to determine the competitive price of their products. More so, $83.5 \%$ of the respondents had effective advertising skills for their products. Gorman et al (2004) observed that for every entrepreneur to succeed in business, such entrepreneur must have effective marketing skills. Again, $86.5 \%$ of the respondents had effective marketing skills. Marketing is the process of getting consumers interested in your company's product or service. This goes in line with Mazur (2005) marketing is the delivery of a standard of living to the society. Furthermore, $31.0 \%$ of the respondents exchange entrepreneurial information with others. $35.0 \%$ and $32.0 \%$ of the respondents respectively develop and maintain favorable relationship with successful entrepreneurs. Also, $89.0 \%$ of the respondents have excellent communication ability. Nwagwugwu and Okoye (2009) good communication planning promotes every business ventures thereby, making such a business to be successful. This also goes in line with what Denyer (2011) perceived that communication ability is dependent on one's ability and skill to listen, read, write and speak. $82.5 \%$ of the respondents are committed to their work. Also, $90.0 \%$ of the respondents are of great confidence. $65.0 \%$ of the respondents are risk taker. This goes in line with David (2008) that every business entails great risk. $69.0 \%$ of the respondents have a high energy level for entrepreneurship. Furthermore, $85.5 \%$ of the respondents are willing to learn about entrepreneurship development. These in line with the findings of Amesi (2009), if we can control and coordinate ourselves effectively in attending to entrepreneurs programs, then we are sure of achieving success. Finally $73.0 \%$ of the respondents embrace new innovations.

The table $2 b$ above shows that utilization of entrepreneurial information among women farmers is high with $55.0 \%$. This means that majority of the women farmers in the study area are utilizing the information they get from entrepreneurship development to boost the economy.

Table 2a: Utilization of Entrepreneurial Information among Rural Women Farmers

\begin{tabular}{|c|c|c|c|c|c|}
\hline $\begin{array}{l}\text { UTILIZATION OF } \\
\text { INFORMATION }\end{array}$ & ALWAYS & OFTEN & SOMETIMES & RARELY & NEVER \\
\hline $\begin{array}{l}\text { I rely heavily on the information } \\
\text { acquired on entrepreneurship. }\end{array}$ & $143(71.5)$ & $27(13.5)$ & $19(9.5)$ & $7(3.5)$ & $4(2.0)$ \\
\hline $\begin{array}{l}\text { I make use of the different types of } \\
\text { support that is offered to people who } \\
\text { want to start their own businesses. }\end{array}$ & $119(59.5)$ & $48(24.0)$ & $32(16.0)$ & $1(0.5)$ & $0(0.0)$ \\
\hline $\begin{array}{l}\text { I delegates tasks and responsibilities } \\
\text { to employees in my business. }\end{array}$ & $48(24.0)$ & $45(22.5)$ & $3(1.5)$ & $45(22.5)$ & $59(29.5)$ \\
\hline I persist in the face of my adversity. & $171(85.5)$ & $18(9.0)$ & $10(5.0)$ & $1(0.5)$ & $0(0.0)$ \\
\hline $\begin{array}{l}\text { I am able to maintain the financial } \\
\text { record of my business. }\end{array}$ & $97(48.5)$ & $92(46.0)$ & $5(2.5)$ & $4(2.0)$ & $2(1.0)$ \\
\hline $\begin{array}{l}\text { I am able to manage the financial } \\
\text { assets of my business. }\end{array}$ & $97(48.5)$ & $90(45.0)$ & $13(6.5)$ & $0(0.0)$ & $0(0.0)$ \\
\hline $\begin{array}{l}\text { I am able to determine the } \\
\text { competitive price of my products. }\end{array}$ & $138(69.0)$ & $51(25.5)$ & $11(5.5)$ & $0(0.0)$ & $0(0.0)$ \\
\hline I have effective advertising skills. & $167(83.5)$ & $21(10.5)$ & $9(4.5)$ & $2(1.0)$ & $1(0.5)$ \\
\hline I have effective marketing skills. & $173(86.5)$ & $21(10.5)$ & $3(1.5)$ & $2(1.0)$ & $1(0.5)$ \\
\hline $\begin{array}{l}\text { I exchange entrepreneurial } \\
\text { information with others. }\end{array}$ & $49(24.5)$ & $48(24.0)$ & $62(31.0)$ & $37(18.5)$ & $4(2.0)$ \\
\hline
\end{tabular}




\begin{tabular}{|c|c|c|c|c|c|}
\hline $\begin{array}{l}\text { I develop and maintain favorable } \\
\text { relationship with successful } \\
\text { entrepreneurs. }\end{array}$ & $70(35.0)$ & $64(32.0)$ & $43(21.5)$ & $21(10.5)$ & $2(1.0)$ \\
\hline $\begin{array}{l}\text { I have excellent communication } \\
\text { ability. }\end{array}$ & $178(89.0)$ & $18(9.0)$ & $4(2.0)$ & $0(0.0)$ & $0(0.0)$ \\
\hline I am very committed to my work. & $165(82.5)$ & $30(15.0)$ & $4(2.0)$ & $1(0.5)$ & $0(0.0)$ \\
\hline I am very self-confident. & $180(90.0)$ & $12(6.0)$ & $5(2.5)$ & $2(1.0)$ & $1(0.5)$ \\
\hline I am a risk taker. & $130(65.0)$ & $66(33.0)$ & $3(1.5)$ & $1(0.5)$ & $0(0.0)$ \\
\hline I have a high energy level. & $138(69.0)$ & $49(24.5)$ & $13(6.5)$ & $0(0.0)$ & $0(0.0)$ \\
\hline $\begin{array}{l}\text { I am willing to learn about } \\
\text { entrepreneurial information } \\
\text { continually. }\end{array}$ & $171(85.5)$ & $21(10.5)$ & $5(2.5)$ & $3(1.5)$ & $0(0.0)$ \\
\hline I embrace new innovations. & $146(73.0)$ & $35(17.5)$ & $18(9.0)$ & $1(0.5)$ & $0(0.0)$ \\
\hline
\end{tabular}

Source: Field Survey, 2018.

Table 2b: Categorization of Respondents based on Utilization of Entrepreneurial Information among Rural Woman farmers.

\begin{tabular}{lcc}
\hline Categorization & Frequency & Percentage \\
\hline High & 110 & 55.0 \\
(Above mean) & & \\
Low & 90 & 45.0 \\
(Below mean) & & \\
Total & $\mathbf{2 0 0}$ & $\mathbf{1 0 0}$ \\
\hline
\end{tabular}

Mean $=27.0$

Source; Computed from Researcher's Survey, 2018.

The result in table 3 shows that $87.0 \%$ and $86.5 \%$ of the respondents respectively stated that securing working capital and insufficient financial assistance by financial institution has been a major constraint in utilizing entrepreneurial information in the study area. This implies that there is no adequate funding either by government or cooperative societies and it makes farmers unable to utilize entrepreneurial information. Also, $48.0 \%$ of the respondents stated that lack of transportation facilities is a major constraint they face. This implies that there is bad transportation network in our rural areas and this always leads to spoilage of products in the process of transporting it to the urban areas while $41.0 \%$ of the respondents also lack market information. Furthermore, the high cost of labor $78.0 \%$ has been a major constraint in utilizing entrepreneurial information. This implies that there is limited number of labors or sometimes limited skilled labor to perform the practice effectively. Also, $71.0 \%$ of the respondents in the study area are faced with gender inequality problems. This implies that, in many cases the women entrepreneurs also faced non acceptance from domestic front. Their family members especially the males of the family were not ready to digest the fact that the women were earning more than them and stepping out of the house. Gender inequality exists in terms of economic development as well as the rates of entrepreneurial activity. This goes in line with the findings of Kelley (2011) A GEM study of 18 economies from 2002 to 2010 suggests that women's entrepreneurial activity is lower than that of their male counterparts at different stages of development. $83.5 \%$ of the respondents in the study area deduced that unfavorable policies made by the government are major constraints. Lastly, $74.0 \%$ of the respondent had low education. This implies that the illiteracy of the farmers has hindered them from effectively utilizing entrepreneurial information. 
The table $3 \mathrm{~b}$ shows that majority $55.0 \%$ of the respondents respondents with low constraints. are faced with high constraints while $45.0 \%$ of the

Table 3a: Constraints Faced by Rural Women Farmers in Utilizing Entrepreneurial Information.

\begin{tabular}{|c|c|c|c|}
\hline Constraints & Major constraints & Minor constraints & Not a constraints \\
\hline \multicolumn{4}{|l|}{ FINANCIAL } \\
\hline Securing working capital. & 174(87.0) & $24(12.0)$ & $2(1.0)$ \\
\hline $\begin{array}{l}\text { Insufficient financial assistance by financial } \\
\text { institutions. }\end{array}$ & $173(86.5)$ & $19(9.5)$ & $8(4.0)$ \\
\hline Inadequate loan. & $167(83.5)$ & $31(15.5)$ & $2(1.0)$ \\
\hline Entire loan is not given at a time. & $167(83.5)$ & $25(12.5)$ & $8(4.0)$ \\
\hline Low price for the produce. & $90(45.0)$ & $105(53.0)$ & $4(2.0)$ \\
\hline Lack of means of production. & $119(59.5)$ & $78(39.0)$ & $3(1.5)$ \\
\hline \multicolumn{4}{|l|}{ MARKETING } \\
\hline Lack of information and network. & $82(41.0)$ & $74(37.0)$ & $44(22.0)$ \\
\hline Lack of transportation facilities. & $96(48.0)$ & $50(25.0)$ & $54(27.0)$ \\
\hline Lack of market information. & $82(41.0)$ & $44(22.0)$ & $74(37.0)$ \\
\hline Delay of payments. & $95(47.5)$ & $69(34.5)$ & $36(18.0)$ \\
\hline \multicolumn{4}{|l|}{ PRODUCTION AND LABOR } \\
\hline High labor cost & $156(78.0)$ & $40(20.0)$ & $4(2.0)$ \\
\hline Non availability of skilled workers. & $138(69.0)$ & $61(30.5)$ & $1(0.5)$ \\
\hline High cost of inputs. & $155(77.5)$ & $39(19.5)$ & $6(3.0)$ \\
\hline \multicolumn{4}{|l|}{ PERSONAL/ GENERAL } \\
\hline Gender inequalities. & $142(71.0)$ & $33(16.5)$ & $25(12.5)$ \\
\hline Unfavorably policies. & $167(83.5)$ & $32(16.0)$ & $1(0.5)$ \\
\hline Health problem & $143(71.5)$ & $50(25.0)$ & $7(3.5)$ \\
\hline $\begin{array}{l}\text { Unfriendly institution that governs the } \\
\text { everyday business and generally in } \\
\text { accessibility of policies. }\end{array}$ & $160(80.0)$ & $33(16.5)$ & $7(3.5)$ \\
\hline Low education. & $148(74.0)$ & $38(19.0)$ & $14(7.0)$ \\
\hline
\end{tabular}

Source: Computed From Researcher’s Survey, 2018. 
International Journal of Environment, Agriculture and Biotechnology, 5(2)

Mar-Apr, 2020 / Available: https://ijeab.com/

Table 3b: Categorization of Respondents Based on Constraints Faced by Rural Women Farmers in Utilizing Entrepreneurial Information

\begin{tabular}{lcc}
\hline Categorization & Frequency & Percentage \\
\hline High & 110 & 55.0 \\
(Above mean) & & \\
Low & 90 & 45.0 \\
(Below mean) & & \\
Total & $\mathbf{2 0 0}$ & $\mathbf{1 0 0}$ \\
\hline
\end{tabular}

Mean $=26.5$

Source: Computed From Researcher's Survey, 2018.

Table 4.10: Ho3: Relationship between constraints faced by rural women farmers and utilization of entrepreneurial information.

\begin{tabular}{|c|c|c|c|}
\hline VARIABLES & r-VALUE & p-VALUE & DECISION \\
\hline $\begin{array}{l}\text { Constraints faced by rural women } 0.365 \\
\text { farmers and utilization of entrepreneurial } \\
\text { information. }\end{array}$ & 0.000 & & $S$ \\
\hline
\end{tabular}

Source: Computed From field Survey, 2018.

The table 4 above shows that there is significant relationship between constraints faced by rural women farmers and utilization of entrepreneurial information (R-value $=0.365$ and $p$ - valve $=0.000$ ). This is in line with the report findings of (Aculai et al., 2006; Aidis, 2006) when necessary resources are available to women entrepreneurs, women still hesitate to set up units or do not succeed in their ventures due to constraint imposed on them by their immediate environment such as family commitments and lack of market opportunity.

\section{CONCLUSION AND RECOMMENDATIONS}

Based on the findings of the study, the following conclusions were drawn: The study reveals that majority of the respondents' belonged to young age group and have highest percentage of married women. It also explains that most of the respondents utilized every information they got on entrepreneurial development and are willing to learn about entrepreneurship information continually. However, Securing working capital, lack of transportation, lack of information and delay of payment, high cost of labor and high cost of inputs are major constraints faced by rural women farmers in the study area. Conclusively, it can be deduced from the study that most of the women farmers are familiar with what entrepreneurship is, but they are hindered, hampered, and incapacitated due to the above mentioned constraints. It is therefore recommended that Rural women farmers should be introduced to the internet, in order to get more information on entrepreneurship. And also, Various tiers of government should create programs that will catalyze entrepreneurial development with the aid entrepreneur information (with special focus for women) in the rural areas.

\section{REFERENCES}

[1] Adelore, O.O., Olujide, M.G. and Popoola, R.A. 2006. Impact of HIV/AIDS Prevention promotion programmes behavioural patterns among rural dwellers in south western Nigeria. Kamla-Raj journal of Human. Ecology, 20, 1: 53-58.

[2] Aculai; E.N. Rodionova and Vinogradova (2006). Women business owners in moldova. Proprietor or Enterpreneurs? In; F. Welter, D smallbone and N. Isakova (Eds.), enterprising women in Transition Economies. Ashgate, Aldershot, pp. 6791.

[3] Amesi, J. (2009). Critical charateristics and qualities needed for successful entrepreneurship as perceived by successful female entrepreneurs in the Niger Delta: Unpublished Ph.D Dissertation, Nnamdi Azikiwe University Awka, Anambra State. 
[4] Baron RA, Henry RA (2010). How Entrepreneurs Acquire the Capacity to Excel: Insights From Research on Expert Performance, Strateg. Entrep. J., 4(1): 49-65.

[5] Biswas UN (2000). Impact of Entrepreneurs' Personality Characteristics on Employee Perception of Organizational Climate in Small-Scale Enterprises. J. Entrepreneurship 9(1): 49-62.

[6] Cuervo Á, Ribeiro D, Roig S (2008). Entrepreneurship: Concepts, Theory and Perspective. Introduction, http://www.uv.es/bcjauveg/ docs/LibroCuervoRibeiroRoigIntroduction.pdf.

[7] David, F. (2008). Global entrepreneurship: opening up new opportunities for people across the country and the world. Journal of Bussiness Venturing.4,212-222.

[8] Kelley DJ, Brush CG, Greene PG, Litovsky Y (2011): Global Entrepreneurship Monitor: 2012

[9] Women's Report. Boston; The Center for Women's Leadership at Babson College and London Business School..

[10] Matanmi, S and Awodun, M (2005). An assessment of competitive strategies and growth patterns of new enterprises in Nigeria using the developing economy model. Lagos organization Review, 26-32.

[11] Nwaogwugwu, P.O. \&Okoye. (2009). Formal and informal communication: implications for the secretary. In Ahukannah, L. T. \&Ugoriji, E.I. (ed) Applied office administrative procedure and business communication. Singapore, Times Printers Limited.

[12] Odebode S. O. (2008): Appropriate Technology for Cassava Processing in Nigeria;

[13] User's Point of View. Journal of International Women Studies. 9 (3): 213-225

[14] Ottun and Moore, W.L,(1997). The role of market information in new product sources/ failure.Journal of product innovation management 14, 258-273.

[15] Piti M (2010). Antreprenor "made in Romania", http://www.postprivatizare.ro/romana/ antreprenor-made-inromania.

[16] Pleter OT (2005). Administer area a facerilor, Second Edition, CarteaUniversitară Publishing House, Bucharest.

[17] UNDP (2006).World development report. Retrieved from www.nationmaster.com/graph/eco_human development. 